\title{
MENILAI KELAYAKAN PENGEMBANGAN SITU-SITU DI KABUPATEN BEKASI SEBAGAI OBYEK DESTINASI WISATA
}

\author{
${ }^{1}$ Astri Mutia Ekasari \\ ${ }^{1}$ Universitas Islam Bandung, Bandung, Jawa Barat, Indonesia \\ E-mail: ${ }^{1}$ astrimutiaekasari@gmail.com
}

\begin{abstract}
Bekasi Regency directs one of the accelerating development policies in the tourism sector by utilizing the natural lake in its administrative area. At present this lake is used to draining irrigation networks and controling floods. This research analyzes the feasibility of lake areas to develop tourist destination objects. The feasibility analysis is based on two criteria indicators, namely the criteria for physical conditions and criteria for assessing tourism potential. Based on the results of the analysis it founds that Situ Cibeureum, Situ Ceper, Situ Binong, Situ Cipalahar, and Situ Tegal Abidin could potentially be developed as a tourist attraction. Development goals must be prioritized on maintaining the environment and improving economic and social standards of local communities, towards sustainable tourism.
\end{abstract}

Key words : lake, tourist destination, maintaining the environment.

\begin{abstract}
Abstrak. Kabupaten Bekasi mengarahkan salah satu kebijakan percepatan pembangunan pada sektor pariwisata dengan memanfaatkan situ-situ alami yang terdapat di wilayah administrasinya. Saat ini situ-situ tersebut difungsikan untuk mengaliri jaringan irigasi dan sebagai pengendali banjir. Penelitian ini mencoba untuk menganalisis kelayakan dari kawasan situ-situ guna pengembangan obyek destinasi wisata. Analisis kelayakan dilakukan berdasarkan dua indikator kriteria, yaitu kriteria kondisi fisik situ dan kriteria penilaian potensi pariwisata. Berdasarkan hasil analisis diperoleh bahwa Situ Cibeureum, Situ Ceper, Situ Binong, Situ Cipalahar, dan Situ Tegal Abidin berpotensi dikembangkan menjadi objek wisata. Tujuan pembangunan situ harus diprioritaskan pada pemeliharaan lingkungan situ serta meningkatkan standar ekonomi dan sosial masyarakat lokal, menuju pariwisata berkelanjutan.
\end{abstract}

Kata kunci : situ, destinasi wisata, pemeliharaan lingkungan.

\section{Pendahuluan}

Pariwisata dikalim sebagai pintu gerbang menuju peningkatan perekonomian bagi masyarakat, terutama di negara berkembang. Pariwisata adalah sektor unggulan yang mengalami ekspansi dan diversifikasi berkelanjutan, menjadi faktor kunci dalam peningkatan pendapatan, penciptaan lapangan kerja, pengembangan usaha, dan infrastruktur (UNWTO, 2014). Pemerintah Indonesia turut mengarahkan salah satu kebijakan percepatan pembangunan nasional pada sektor pariwisata, dengan mendorong pembangunan destinasi wisata nasional.

Kebijakan nasional tersebut diturunkan oleh Kabupaten Bekasi dalam kebijakan tata ruang wilayahnya, selain menitikberatkan pada pembangunan industri, juga mendorong pertumbuhan ekonomi melalui perdagangan dan pariwisata secara luas. Salah satu programnya dengan menempatkan kegiatan wisata alam sebagai basis pengembangan daya tarik dan potensi lokal, berupa destinasi 
wisata alam pada kawasan-kawasan yang dilindungi misalnya taman kota, hutan kota, kebun raya dan kawasan situ.

Kabupaten Bekasi memiliki 14 situ alami yang lokasi nya tersebar di beberapa kecamatan (data inventaris BBWSCC, 2012). Sebagian besar sumber air yang mengaliri situ-situ berasal dari curah hujan, mata air dan sungai. Situ-situ tersebut difungsikan untuk mengaliri jaringan irigasi dan sebagai pengendali banjir. Namun kondisi beberapa situ saat ini mulai terganggu fungsinya, hal ini dipicu oleh perubahan lahan di daerah tangkapan air dan hulu sungai yang menyebabkan penurunan volume/debit air. Bahkan secara fisik teridentifikasi 3 (tiga) situ yang telah beralih fungsi menjadi permukiman, industri, dan perdagangan/jasa.

Upaya pemanfaatan kawasan situ menjadi destinasi wisata dapat memberikan dampak negatif yang lebih buruk bagi kondisi lingkungan situ. Namun pariwisata juga memiliki potensi untuk menciptakan efek menguntungkan bagi kondisi lingkungan situ dengan berkontribusi terhadap perlindungan lingkungan dan konservasi. Melalui pengembangan ekowisata sebagai cara untuk meningkatkan kesadaran pengunjung dan masyarakat terhadap nilai-nilai lingkungan, sekaligus berfungsi sebagai alat untuk meningkatkan pendapatan keuangan daerah dan meningkatan kepentingan ekonomi masyarakat lokal (Dokulil, 2014).

Penelitian ini mencoba untuk menganalisis kelayakan dari kawasan situ yang masih ada di Kabupaten Bekasi guna pengembangan destinasi wisata. Analisis kelayakan dilakukan berdasarkan dua indikator kriteria, yaitu 1) Kriteria kondisi fisik situ, dan 2) Kriteria penilaian potensi pariwisata.

\section{Metodologi Penelitian}

Obyek studi kawasan situ-situ diobservasi secara detail untuk mendapatkan data dan informasi yang diperlukan dalam penilaian kelayakannya. Penjabaran indikator kriteria penilaian, yaitu 1) Kriteria kondisi fisik situ, mencakup badan situ, batas situ, bangunan pelengkap, vegetasi air, dan kualitas air; 2) Kriteria penilaian potensi pariwisata, meliputi ketersediaan lahan pengembangan, keragaman daya tarik, keunikan obyek wisata, jumlah wisatawan, jangkauan pasar, ketersediaan moda angkutan umum, kemudahan pencapaian, ketersediaan sarana prasarana pendukung disekitarnya, kelengkapan fasilitas dasar, keberadaan SDM/pengelola.

Data dan informasi tersebut diukur/dinilai dengan Skala Likert. Informasi pada kriteria yang menunjukkan kondisi baik diberi skor tertinggi, sebaliknya informasi pada kriteria yang menunjukkan kondisi tidak baik diberi skor lebih rendah. Skala ini menggunakan ukuran ordinal sehingga total skor pada masing-masing kriteria dapat ditafsirkan sebagai posisi kelayakan situ yang diamati. Panduan penilaian kelayakan Situ berdasarkan indikator kriteria kondisi fisik dan potensi pariwisata dapat dilihat pada Tabel 1 dan Tabel 3. 
Tabel Error! No text of specified style in document.. Kriteria Penilaian Kualitas Situ

\begin{tabular}{|c|c|c|c|c|}
\hline No & $\begin{array}{c}\text { Kriteria } \\
\text { Aspek }\end{array}$ & Parameter & Kondisi Parameter & Nilai Bobot \\
\hline \multirow{9}{*}{1} & \multirow{9}{*}{$\begin{array}{l}\text { Badan } \\
\text { Situ }\end{array}$} & \multirow{3}{*}{$\begin{array}{l}\text { Penyusutan luas } \\
\text { dalam } 10 \text { tahun } \\
\text { terakhir }\end{array}$} & Tinggi $(>25 \%)$ & 1 \\
\hline & & & Sedang $(5-25 \%)$ & 2 \\
\hline & & & Rendah $(<5 \%)$ & 3 \\
\hline & & \multirow{3}{*}{$\begin{array}{l}\text { Kedalaman } \\
\text { musim hujan }\end{array}$} & Dangkal $(<2 \mathrm{~m})$ & 1 \\
\hline & & & Sedang $(2-5 \mathrm{~m})$ & 2 \\
\hline & & & Rendah (> $5 \mathrm{~m})$ & 3 \\
\hline & & \multirow{3}{*}{$\begin{array}{l}\text { Penurunan muka } \\
\text { air pada musim } \\
\text { kemarau }\end{array}$} & Tinggi $(>50 \%)$ & 1 \\
\hline & & & Sedang $(25-50 \%)$ & 2 \\
\hline & & & Rendah $(<25 \%)$ & 3 \\
\hline \multirow{3}{*}{2} & \multirow{3}{*}{$\begin{array}{l}\text { Batas- } \\
\text { batas Situ }\end{array}$} & \multirow{3}{*}{ Sempadan } & Tidak ada & 1 \\
\hline & & & $\begin{array}{l}\text { Ada, tidak jelas, sebagian } \\
\text { sempadan beralih menjadi } \\
\text { penggunaan lain (ladang, rumah, } \\
\text { dll) }\end{array}$ & 2 \\
\hline & & & Ada, jelas, sempadan relatif hijau & 3 \\
\hline \multirow{3}{*}{3} & \multirow{3}{*}{$\begin{array}{l}\text { Bangunan } \\
\text { Air }\end{array}$} & \multirow{3}{*}{$\begin{array}{l}\text { Cekdam dan } \\
\text { Pintu Air }\end{array}$} & Tidak ada & 1 \\
\hline & & & Ada, tidak berfungsi & 2 \\
\hline & & & Ada, berfungsi baik & 3 \\
\hline \multirow{3}{*}{4} & \multirow{3}{*}{$\begin{array}{l}\text { Vegetasi } \\
\text { Air }\end{array}$} & \multirow{3}{*}{$\begin{array}{l}\text { Prosentase } \\
\text { Tutupan }\end{array}$} & $>50 \%$ & 1 \\
\hline & & & $25-50 \%$ & 2 \\
\hline & & & $<25 \%$ & 3 \\
\hline \multirow{3}{*}{5} & \multirow{3}{*}{$\begin{array}{l}\text { Kualitas } \\
\text { Air }\end{array}$} & \multirow{3}{*}{ Baku Mutu Air } & Sesuai baku mutu air kelas IV & 1 \\
\hline & & & Sesuai baku mutu air kelas III & 2 \\
\hline & & & Sesuai baku mutu air kelas I \& II & 3 \\
\hline \multicolumn{4}{|c|}{ Total Nilai Bobot Tertinggi } & 21 \\
\hline
\end{tabular}

Sumber: Rahman, 2010

Hasil penilaian sesuai parameter penilaian pada masing-masing situ lalu dijumlahkan bobot penilaiannya, sehingga dihasilkan variasi bobot yang dapat dikategorikan menjadi 3 kelas kualitas fisik yaitu Rusak, Terganggu, dan Baik sebagaimana tersaji pada Tabel 2 tentang Penilaian Kualitas Fisik Situ.
Tabel 2. Penilaian Kualitas Fisik Situ

\begin{tabular}{|c|c|}
\hline $\begin{array}{c}\text { Total Nilai } \\
\text { Bobot }\end{array}$ & $\begin{array}{c}\text { Kategori Kualitas } \\
\text { Situ }\end{array}$ \\
\hline $7-11$ & Buruk/Rusak \\
\hline $12-16$ & Terganggu \\
\hline $17-21$ & Baik \\
\hline
\end{tabular}

Tabel 3. Kriteria Penilaian Potensi Pariwisata

\begin{tabular}{|c|c|c|c|c|}
\hline \multirow{2}{*}{ No } & \multirow{2}{*}{$\begin{array}{l}\text { Rincian Unsur } \\
\text { Penilaian }\end{array}$} & \multicolumn{3}{|c|}{ Penilaian } \\
\hline & & Nilai 1 & Nilai 2 & Nilai 3 \\
\hline 1 & $\begin{array}{l}\text { Kondisi } \\
\text { lingkungan dinilai } \\
\text { dari kondisi fisik } \\
\text { serta ketersediaan }\end{array}$ & $\begin{array}{l}\text { Kondisi objek } \\
\text { terganggu dan } \\
\text { tidak memiliki } \\
\text { lahan untuk }\end{array}$ & $\begin{array}{l}\text { Kondisi objek } \\
\text { terganggu dan } \\
\text { masih memiliki } \\
\text { lahan untuk }\end{array}$ & $\begin{array}{l}\text { Kondisi objek } \\
\text { baik dan masih } \\
\text { memiliki lahan } \\
\text { untuk }\end{array}$ \\
\hline
\end{tabular}




\begin{tabular}{|c|c|c|c|c|}
\hline \multirow{2}{*}{ No } & \multirow{2}{*}{$\begin{array}{c}\text { Rincian Unsur } \\
\text { Penilaian } \\
\end{array}$} & \multicolumn{3}{|c|}{ Penilaian } \\
\hline & & Nilai 1 & Nilai 2 & Nilai 3 \\
\hline & $\begin{array}{l}\text { lahan untuk } \\
\text { pengembangan } \\
\text { objek wisata }\end{array}$ & $\begin{array}{l}\text { pengembangan } \\
\text { objek }\end{array}$ & $\begin{array}{l}\text { pengembangan } \\
\text { objek }\end{array}$ & $\begin{array}{l}\text { pengembangan } \\
\text { objek }\end{array}$ \\
\hline 2 & $\begin{array}{l}\text { Keragaman daya } \\
\text { tarik dinilai dari } \\
\text { banyaknya daya } \\
\text { tarik yang dimiliki } \\
\text { oleh objek tersebut }\end{array}$ & $\begin{array}{l}\text { Bila objek hanya } \\
\text { memiliki satu } \\
\text { daya tarik }\end{array}$ & $\begin{array}{l}\text { Bila objek } \\
\text { memiliki tiga } \\
\text { daya tarik }\end{array}$ & $\begin{array}{l}\text { Bila objek } \\
\text { memiliki lima } \\
\text { daya tarik atau } \\
\text { lebih }\end{array}$ \\
\hline 3 & $\begin{array}{l}\text { Keunikan objek } \\
\text { wisata dinilai dari } \\
\text { daya tariknya } \\
\text { apakah dapat } \\
\text { ditemukan di } \\
\text { tempat lain atau } \\
\text { tidak }\end{array}$ & $\begin{array}{l}\text { Bila objek banyak } \\
\text { ditemukan di } \\
\text { tempat lain dan } \\
\text { tidak memiliki } \\
\text { keunikan }\end{array}$ & $\begin{array}{l}\text { Bila objek jarang } \\
\text { ditemukan di } \\
\text { tempat lain dan } \\
\text { memiliki } \\
\text { keunikan }\end{array}$ & $\begin{array}{l}\text { Bila objek tidak } \\
\text { ditemukan di } \\
\text { tempat lain } \\
\text { dengan keunikan } \\
\text { tersendiri }\end{array}$ \\
\hline 4 & $\begin{array}{l}\text { Besarnya jumlah } \\
\text { wisatawan yang } \\
\text { datang ke objek } \\
\text { wisata }\end{array}$ & $\begin{array}{l}\text { Bila tingkat } \\
\text { kunjungan kurang } \\
\text { dari } 10.000 \text { orang } \\
\text { per bulan }\end{array}$ & $\begin{array}{l}\text { Bila tingkat } \\
\text { kunjungan antara } \\
10.000-50.000 \\
\text { orang per bulan }\end{array}$ & $\begin{array}{l}\text { Bila tingkat } \\
\text { kunjungan lebih } \\
\text { dari } 50.000 \text { orang } \\
\text { per bulan }\end{array}$ \\
\hline 5 & $\begin{array}{l}\text { Luas jangkauan } \\
\text { pemanfaatan } \\
\text { wisatawan } \\
\text { terhadap objek } \\
\text { wisata }\end{array}$ & $\begin{array}{l}\text { Bila jangkauan } \\
\text { wisatawan masih } \\
\text { lokal }\end{array}$ & $\begin{array}{l}\text { Bila jangkauan } \\
\text { wisatawan } \\
\text { sampai kota-kota } \\
\text { lain di pulau } \\
\text { Jawa }\end{array}$ & $\begin{array}{l}\text { Bila jangkauan } \\
\text { wisatawan } \\
\text { mencapai tingkat } \\
\text { nasional dan } \\
\text { internasional }\end{array}$ \\
\hline 6 & $\begin{array}{l}\text { Ketersediaan moda } \\
\text { transportasi } \\
\text { menuju objek } \\
\text { wisata } \\
\end{array}$ & $\begin{array}{l}\text { Bila tidak ada } \\
\text { ketersediaan } \\
\text { moda transportasi }\end{array}$ & $\begin{array}{l}\text { Bila terdapat } \\
\text { moda transportasi } \\
\text { tetapi sangat } \\
\text { kurang }\end{array}$ & $\begin{array}{l}\text { Bila ketersediaan } \\
\text { moda transportasi } \\
\text { banyak }\end{array}$ \\
\hline 7 & $\begin{array}{l}\text { Kemudahan } \\
\text { pencapaian, yaitu } \\
\text { berhubungan } \\
\text { dengan kualitas } \\
\text { jalan serta } \\
\text { kemudahan karena } \\
\text { adanya rambu- } \\
\text { rambu petunjuk }\end{array}$ & $\begin{array}{l}\text { Bila tempat sulit } \\
\text { ditemukan karena } \\
\text { kurangnya } \\
\text { rambu-rambu } \\
\text { petunjuk arah dan } \\
\text { sulitnya jalan }\end{array}$ & $\begin{array}{l}\text { Bila rambu- } \\
\text { rambu petunjuk } \\
\text { arah kurang } \\
\text { tetapi medan } \\
\text { jalan cukup baik }\end{array}$ & $\begin{array}{l}\text { Bila rambu- } \\
\text { rambu petunjuk } \\
\text { arah cukup baik } \\
\text { dan waktu } \\
\text { tempuh dari jalan } \\
\text { utama cukup } \\
\text { cepat }\end{array}$ \\
\hline 8 & $\begin{array}{l}\text { Ketersediaan } \\
\text { sarana dan } \\
\text { prasarana dinilai } \\
\text { dari kondisinya } \\
\text { apakah masih } \\
\text { berfungsi baik atau } \\
\text { tidak }\end{array}$ & $\begin{array}{l}\text { Sarana dan } \\
\text { prasarana tidak } \\
\text { berfungsi bahkan } \\
\text { tidak ada sama } \\
\text { sekali }\end{array}$ & $\begin{array}{l}\text { Sarana dan } \\
\text { prasarana } \\
\text { berfungsi namun } \\
\text { tidak terawat }\end{array}$ & $\begin{array}{l}\text { Sarana dan } \\
\text { prasarana } \\
\text { berfungsi dan } \\
\text { terawat baik }\end{array}$ \\
\hline 9 & $\begin{array}{l}\text { Ketersediaan hotel } \\
\text { atau penginapan di } \\
\text { sekitar objek } \\
\text { wisata }\end{array}$ & $\begin{array}{l}\text { Tidak ada } \\
\text { penginapan di } \\
\text { sekitar objek } \\
\text { wisata }\end{array}$ & $\begin{array}{l}\text { Ada penginapan } \\
\text { namun } \\
\text { kapasitasnya } \\
\text { terbatas }\end{array}$ & $\begin{array}{l}\text { Ada penginapan } \\
\text { dan kapasitasnya } \\
\text { banyak }\end{array}$ \\
\hline
\end{tabular}




\begin{tabular}{|c|l|l|l|l|}
\hline \multirow{2}{*}{ No } & \multicolumn{1}{|c|}{$\begin{array}{c}\text { Rincian Unsur } \\
\text { Penilaian }\end{array}$} & \multicolumn{1}{|c|}{ Nilai 1 } & \multicolumn{1}{|c|}{ Nilai 2 } & \multicolumn{1}{|c|}{ Nilai 3 } \\
\cline { 3 - 5 } 10 & $\begin{array}{l}\text { Kelengkapan } \\
\text { sarana fasilitas } \\
\text { penunjang yang } \\
\text { ada (rumah makan, } \\
\text { parkir, toilet, } \\
\text { tempat } \\
\text { peribadatan, toko } \\
\text { cinderamata) }\end{array}$ & $\begin{array}{l}\text { Tidak ada satupun } \\
\text { sarana penunjang } \\
\text { di objek wisata }\end{array}$ & $\begin{array}{l}\text { Bila hanya ada } \\
\text { rumah makan, } \\
\text { parkir dan toitel } \\
\text { di objek wisata }\end{array}$ & $\begin{array}{l}\text { Sarana penunjang } \\
\text { lengkap termasuk } \\
\text { toko cinderamata }\end{array}$ \\
\hline 11 & $\begin{array}{l}\text { Keberadaan SDM } \\
\text { atau lembaga } \\
\text { pengelola }\end{array}$ & $\begin{array}{l}\text { Tidak ada } \\
\text { pengelola objek } \\
\text { wisata }\end{array}$ & $\begin{array}{l}\text { Pengelola hanya } \\
\text { pemerintah }\end{array}$ & $\begin{array}{l}\text { Ada pengelola } \\
\text { dari swasta dan } \\
\text { pemerintah }\end{array}$ \\
\hline 12 & $\begin{array}{l}\text { Promosi terhadap } \\
\text { objek wisata }\end{array}$ & $\begin{array}{l}\text { Tidak ada } \\
\text { promosi }\end{array}$ & Ada promosi & $\begin{array}{l}\text { Ada promosi dan } \\
\text { pusat informasi }\end{array}$ \\
\hline
\end{tabular}

Sumber: Rahman, 2010

Pada kategori penilaian potensi pariwisata juga dilakukan hal yang sama, dimana hasil penilaian masing-masing situ dijumlahkan bobot nilainya, sehingga dihasilkan variasi bobot yang dapat dikategorikan menjadi 3 kelas potensi situ yaitu Kurang Berpotensi, Cukup Berpotensi, dan Berpotensi. Kategori kelas potensi pariwisata situ sebagai objek wisata dapat dilihat pada Tabel 4 tentang Penilaian Potensi Pariwisata sebagai berikut:

Tabel 4. Penilaian Potensi Pariwisata

\begin{tabular}{|c|c|}
\hline Total Nilai Bobot & Kategori Potensi Situ \\
\hline $12-19$ & Kurang Berpotensi \\
\hline $20-28$ & Cukup Berpotensi \\
\hline $29-36$ & Berpotensi \\
\hline \multicolumn{2}{|c}{ Sumber: Rahman, 2010 }
\end{tabular}

\section{Hasil dan Pembahasan}

\section{Situ dan Pemanfaatannya}

Situ dalam KBBI berarti juga danau atau telaga. Masyarakat Jawa Barat biasa menyebut danau kecil dengan sebutan Situ. Secara definisi, Situ adalah wadah genangan air di atas permukaan tanah yang terbentuk secara alami maupun buatan yang airnya berasal dari tanah atau air permukaan sebagai siklus hidrologis yang merupakan salah satu bentuk kawasan lindung (Perpres No. 54 Tahun 2008). Keberadaan situ secara alami berfungsi untuk menampung kelebihan run-off dimusim penghujan dan mencegah terjadinya banjir. Sedangkan pada musim kemarau bermanfaat untuk mengairi lahan pertanian sawah tadah hujan, sumber minuman bagi ternak, tempat hidup berbagai jenis hewan air yang bernilai ekonomis, dan sumber air masyarakat sekitarnya.

Indonesia memiliki 735 situ alami (danau kecil), 14 situ diantaranya berada di Kabupaten Bekasi. Permasalahan yang dihadapai situ yaitu perubahan fluktuasi muka air, penurunan luasan situ, hingga terjadi alih fungsi situ menjadi kegiatan budidaya. Menurut Muhtadi (2017), permasalahan tersebut antara lain disebabkan oleh kerusakan DAS dan DTA. Kondisi DAS dan DTA yang rusak menyebabkan debit run-off di musim hujan sangat tinggi sehingga lahan tidak mampu menyerap dan menyimpan air hujan, sedangkan debit sangat rendah di musim kemarau dengan perbedaan yang sangat drastis. Sebagai akibatnya, luas dan kedalaman 
danau/situ juga berubah cepat mengikuti musim. Kondisi permasalahan tersebut juga terjadi pada danau dangkal dan danau paparan banjir seperti Danau Tempe, Danau Limboto, serta Situ-situ di wilayah Jabotabek.

Untuk itu, pemanfaatan lahan sekitar kawasan situ harus diperhatikan. Peningkatan kualitas fungsi lindung dapat diwujudkan melalui kegiatan penataan ruang yang meliputi perencanaan tata ruang, pemanfaatan ruang serta pengendalian pemanfaatan ruang yang berkelanjutan. Diharapkan dapat menunjang keberadaan situ/danau/waduk serta fungsinya yang sangat vital tidak hanya bagi lingkungan secara keseluruhan, tapi juga pemanfaatannya untuk kegiatan budidaya yang dilakukan oleh manusia (Kutarga, 2008).

Banyak danau di seluruh dunia digunakan untuk ekowisata, rekreasi, olahraga, dan biasanya menarik banyak wisatawan. Sehingga danau dapat secara signifikan berkontribusi pada pengembangan sosial-ekonomi masyarakat setempat (Tikkanen, 2003). Situ dengan pemandangan alam yang indah dan relatif luas berpotensi untuk dimanfaatkan oleh kegiatan wisata dan olahraga air, seperti Situ Gunung Putri dan Situ Cigudeg di Bogor, Jawa Barat (Puspita, 2005).

Perencanaan yang efektif adalah dasar dari manajemen pariwisata yang kuat untuk mencapai keseimbangan yang optimal, antara dampak pariwisata berkelanjutan sekaligus perlindungan terhadap ekosistem danau (Kurleto, 2013). Upaya pemulihan ekosistem danau harus dapat memperkuat kontrol terhadap polusi danau dan kegiatan rehabilitasi danau, sehingga jasa ekosistem danau dapat segera dipulihkan dan memberikan kontribusi positif pada perkembangan ekologi danau (Wuhan, 2009).

Situ-situ di Kabupaten Bekasi pada umumnya merupakan bagian dari saluran irigasi, berfungsi sebagai tampungan air untuk menyuplai air ke sawah/kebun maupun tampungan air sebagai pengendali banjir. Secara umum kondisi situ di Kabupaten Bekasi mengalami penurunan kualitas fisik, sembilan dari empat belas situ mengalami penyusutan luasan karena terjadi konversi lahan situ menjadi pemanfaatan lahan lainnya seperti sawah, ladang, industri, bahkan rumah penduduk. Selain itu, terjadi penurunan muka air situ pada saat musim kemarau yang cukup signifikan, bahkan 6 (enam) situ diantaranya mengalami kekeringan. Hal tersebut tentu saja akan mengganggu keberlangsungan situ sebagai obyek destinasi wisata. Perkembangan luasan situ-situ di Kabupaten Bekasi dapat dilihat pada Gambar 1. 


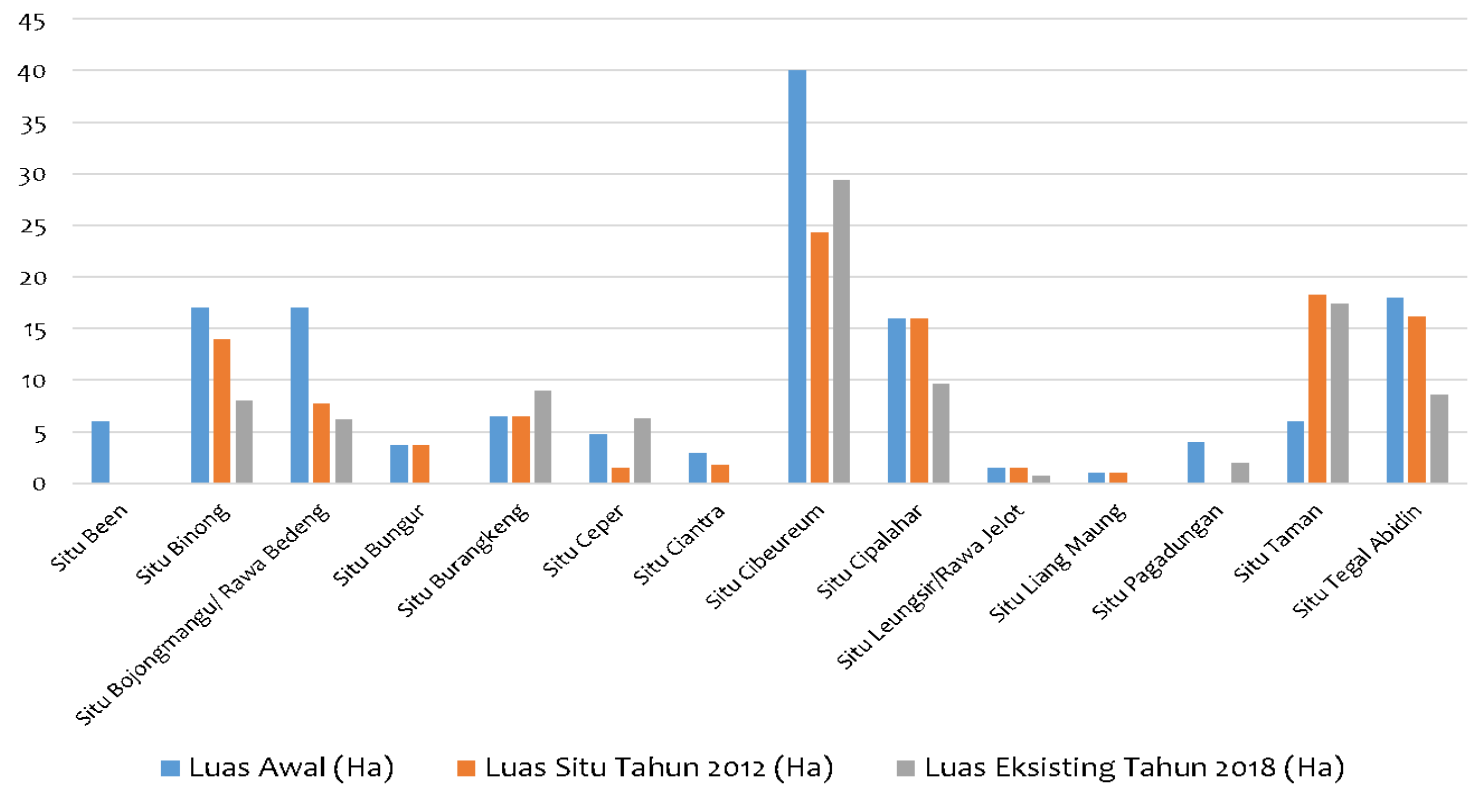

Gambar 1. Perkembangan Luasan Situ-Situ di Kabupaten Bekasi

Sumber : Balai Besar Wilayah Sungai Ciliwung Cisdane, 2018

Beberapa situ seperti Situ Binong, Situ Ceper, Situ Cibeureum, Situ Cipalahar, dan Situ Tegal Abidin diidentifikasi berada pada kondisi yang cukup terawat karena masih ada kegiatan pemeliharaan rutin oleh BBWSCC. Bahkan Situ Binong, Situ Cibeureum, dan Situ Tegal Abidin biasa dikunjungi oleh masyarakat setempat untuk menikmati pemandangan, memancing, rekreasi, piknik, tempat berkumpulnya kegiatan komunitas, dan sebagainya, karena air situ yang tidak mengering meskipun saat musim kemarau dan juga lokasinya yang mudah untuk diakses. Pada umumnya jumlah pengunjung yang datang ke situ-situ masih sangat sedikit, kecuali pada Situ Cibeureum dan Situ Binong.

Tabel 5. Penilaian Kondisi Fisik Situ

\begin{tabular}{|c|c|c|c|c|c|c|c|c|c|c|c|c|c|c|c|}
\hline $\mathbf{N}$ & \multirow{2}{*}{ Parameter Penilaian } & \multicolumn{14}{|c|}{ Nilai Bobot } \\
\hline ( & & $\mathbf{A}$ & B & $\mathbf{C}$ & D & $\mathbf{E}$ & $\mathbf{F}$ & G & $\mathbf{H}$ & I & $\mathbf{J}$ & $\mathbf{K}$ & $\mathbf{L}$ & $\mathbf{M}$ & $\mathbf{N}$ \\
\hline 1 & Penyusu & \multirow{4}{*}{ E } & 1 & 1 & \multirow{4}{*}{$\frac{\frac{\pi}{0}}{\Theta}$} & 3 & 3 & \multirow{4}{*}{$\frac{\frac{\pi}{0}}{\oplus}$} & 1 & 1 & 1 & 3 & 1 & 3 & 1 \\
\hline 2 & Kedalaman musim hujan & & 2 & 2 & & 2 & 3 & & 2 & 2 & 2 & 2 & 1 & 2 & 2 \\
\hline 3 & $\begin{array}{l}\text { Penurunan muka air pada } \\
\text { musim kemarau }\end{array}$ & & 2 & 1 & & 1 & 2 & & 2 & 2 & 1 & 1 & 1 & 1 & 2 \\
\hline 4 & Sempadan & & 2 & 2 & & 2 & 2 & & 2 & 2 & 2 & 2 & 2 & 2 & 2 \\
\hline
\end{tabular}




\begin{tabular}{|c|c|c|c|c|c|c|c|c|c|c|c|c|}
\hline 5 & Cekdam \& Pintu Air & 3 & 2 & 2 & 3 & 1 & 3 & 1 & 1 & 1 & 1 & 3 \\
\hline 6 & Prosentase tutupan vegetasi & 3 & 0 & 0 & 3 & 3 & 3 & 0 & 0 & 0 & 0 & 3 \\
\hline 7 & Baku Mutu air & 3 & 3 & 3 & 3 & 3 & 3 & 3 & 3 & 3 & 3 & 3 \\
\hline & Jumlah & & $\begin{array}{l}1 \\
1 \\
\end{array}$ & $\begin{array}{l}\mathbf{1} \\
\mathbf{3}\end{array}$ & $\begin{array}{l}1 \\
9\end{array}$ & $\begin{array}{l}1 \\
4\end{array}$ & $\begin{array}{l}1 \\
6\end{array}$ & $\begin{array}{l}\mathbf{1} \\
\mathbf{0}\end{array}$ & $\begin{array}{l}1 \\
2\end{array}$ & 9 & $\begin{array}{l}1 \\
2\end{array}$ & $\begin{array}{l}1 \\
6\end{array}$ \\
\hline
\end{tabular}

Sumber : Hasil Analisis, 2018

Keterangan :
A. Situ Been
B. Situ Binong
D. Situ Bungur
E. Situ Burangkeng
C. Situ Bojongmangu
G. Situ Ciantra
H. Situ Cibeureum
F. Situ Ceper
J. Situ Leungsir
K. Situ Liang Maung
M. Situ Taman
N. Situ Tegal Abidin
I. Situ Cipalahar
L. Situ Pagadungan

\section{Analisis Kelayakan Potensi Pariwisata}

Analisis potensi pariwisata bertujuan untuk mengetahui potensi situ-situ di Kabupaten Bekasi sebagai suatu objek wisata, dinilai dari aspek penawaran pariwisata berupa keragaman atraksi wisata, ketersediaan moda transportasi, kemudahan pencapaian, prasarana dasar, sarana penunjang pariwisata, dan peran kelembagaan/pengelola. Hasil penilaian potensi pariwisata dari ke 14 (empat belas) kawasan situ dapat dilihat pada Tabel 6 tentang Penilaian Potensi Pariwisata, berikut ini:

Tabel 6. Penilaian Potensi Pariwisata

\begin{tabular}{|c|c|c|c|c|c|c|c|c|c|c|c|c|c|c|c|}
\hline \multirow{2}{*}{$\begin{array}{l}\mathbf{N} \\
\mathbf{0}\end{array}$} & \multirow{2}{*}{ Parameter Penilaian } & \multicolumn{14}{|c|}{ Nilai Bobot } \\
\hline & & $\mathbf{A}$ & B & $\mathbf{C}$ & D & $\mathbf{E}$ & $\mathbf{F}$ & $\mathbf{G}$ & $\mathbf{H}$ & I & $\mathbf{J}$ & $\mathbf{K}$ & $\mathbf{L}$ & $\mathbf{M}$ & $\mathbf{N}$ \\
\hline 1 & Kondisi lingkungan & \multirow{12}{*}{ 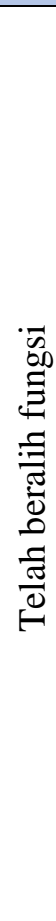 } & 3 & 1 & \multirow{13}{*}{ 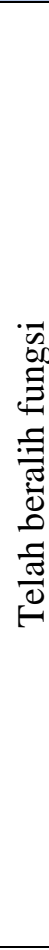 } & 1 & 3 & \multirow{13}{*}{ 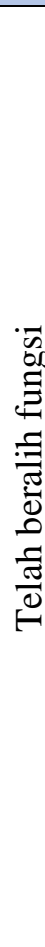 } & 3 & 3 & 1 & 1 & 1 & 1 & 3 \\
\hline 2 & Keragaman atraksi wisata & & 3 & 2 & & 1 & 2 & & 3 & 2 & 1 & 1 & 1 & 1 & 2 \\
\hline 3 & Keunikan obyek wisata & & 3 & 1 & & 1 & 1 & & 1 & 1 & 1 & 1 & 1 & 1 & 3 \\
\hline 4 & Jumlah pengunjung & & 1 & 1 & & 0 & 1 & & 1 & 1 & 0 & 0 & 0 & 0 & 1 \\
\hline 5 & Luas jangkauan & & 1 & 1 & & 1 & 1 & & 1 & 1 & 0 & 0 & 0 & 0 & 1 \\
\hline 6 & $\begin{array}{l}\text { Ketersediaan moda } \\
\text { transportasi }\end{array}$ & & 3 & 2 & & 2 & 2 & & 3 & 2 & 2 & 2 & 2 & 3 & 2 \\
\hline 7 & Kemudahan pencapaian & & 2 & 1 & & 1 & 3 & & 3 & 3 & 2 & 1 & 1 & 2 & 3 \\
\hline 8 & $\begin{array}{l}\text { Ketersediaan prasarana } \\
\text { penunjang }\end{array}$ & & 2 & 1 & & 1 & 1 & & 1 & 1 & 1 & 1 & 1 & 1 & 2 \\
\hline 9 & $\begin{array}{l}\text { Ketersediaan tempat } \\
\text { penginapan }\end{array}$ & & 2 & 1 & & 1 & 1 & & 2 & 1 & 2 & 1 & 1 & 1 & 1 \\
\hline $\begin{array}{l}1 \\
0\end{array}$ & $\begin{array}{l}\text { Kelengkapan sarana } \\
\text { penunjang }\end{array}$ & & 3 & 1 & & 1 & 1 & & 3 & 1 & 1 & 1 & 1 & 1 & 2 \\
\hline $\begin{array}{l}1 \\
1\end{array}$ & $\begin{array}{l}\text { Keberadaan SDM atau } \\
\text { lembaga } \\
\text { pengelola }\end{array}$ & & 3 & 1 & & 1 & 3 & & 1 & 3 & 3 & 3 & 1 & 3 & 2 \\
\hline $\begin{array}{l}1 \\
2\end{array}$ & $\begin{array}{l}\text { Promosi terhadap obyek } \\
\text { wisata }\end{array}$ & & 2 & 1 & & 1 & 1 & & 2 & 1 & 1 & 1 & 1 & 1 & 1 \\
\hline & Jumlah & & $\begin{array}{l}2 \\
8\end{array}$ & $\begin{array}{l}1 \\
4\end{array}$ & & $\begin{array}{l}1 \\
2\end{array}$ & $\begin{array}{l}2 \\
\mathbf{0}\end{array}$ & & $\begin{array}{l}2 \\
5\end{array}$ & $\begin{array}{l}2 \\
\mathbf{0}\end{array}$ & $\begin{array}{l}1 \\
5\end{array}$ & $\begin{array}{l}\mathbf{1} \\
\mathbf{3}\end{array}$ & $\begin{array}{l}1 \\
1\end{array}$ & $\begin{array}{l}1 \\
5\end{array}$ & $\begin{array}{l}2 \\
3\end{array}$ \\
\hline
\end{tabular}

Sumber : Hasil Analisis, 2018 
Rekap Hasil Analisis Kelayakan

\section{Kondisi Fisik dan Potensi Pariwisata}

Rekapitulasi hasil penilaian kondisi fisik dan potensi pariwisata terhadap situ-situ di Kabupaten Bekasi ditunjukkan pada Tabel $\mathbf{7}$ tentang Matriks Penilaian Kondisi Fisik dan Potensi Pariwisata situ sebagai destinasi wisata.

Tabel 7. Matriks Penilaian Kondisi Fisik dan Potensi Pariwisata

\begin{tabular}{|c|c|c|c|c|c|c|c|c|}
\hline \multirow{2}{*}{ No } & \multirow{2}{*}{ Nama Situ } & \multicolumn{3}{|c|}{ Kualitas Fisik } & \multicolumn{3}{|c|}{ Potensi Sebagai Objek Wisata } & \multirow{2}{*}{ Penilaian } \\
\hline & & Baik & Terganggu & Rusak & Berpotensi & Cukup & Kurang & \\
\hline $\mathrm{A}$ & Situ Been & \multicolumn{7}{|c|}{ Telah beralih fungsi } \\
\hline $\mathrm{B}$ & Situ Binong & & $\mathrm{v}$ & & & $\mathrm{v}$ & & Layak \\
\hline $\mathrm{C}$ & $\begin{array}{l}\text { Situ } \\
\text { Bojongmangu/ } \\
\text { Rawa Bedeng }\end{array}$ & & & $\mathrm{v}$ & & & $\mathrm{v}$ & $\begin{array}{l}\text { Tidak } \\
\text { Layak }\end{array}$ \\
\hline $\mathrm{D}$ & $\begin{array}{l}\text { Situ Bungur/ } \\
\text { Cibungur }\end{array}$ & \multicolumn{7}{|c|}{ Telah beralih fungsi } \\
\hline $\mathrm{E}$ & $\begin{array}{l}\text { Situ } \\
\text { Burangkeng }\end{array}$ & & $\mathrm{v}$ & & & & $\mathrm{v}$ & $\begin{array}{l}\text { Tidak } \\
\text { Layak }\end{array}$ \\
\hline $\mathrm{F}$ & Situ Ceper & $\mathrm{V}$ & & & & $\mathrm{V}$ & & Layak \\
\hline $\mathrm{G}$ & Situ Ciantra & \multicolumn{7}{|c|}{ Telah beralih fungsi } \\
\hline $\mathrm{H}$ & $\begin{array}{l}\text { Situ } \\
\text { Cibeureum }\end{array}$ & & $\mathrm{v}$ & & $\mathrm{v}$ & & & Layak \\
\hline $\mathrm{I}$ & Situ Cipalahar & & $\mathrm{V}$ & & & $\mathrm{V}$ & & Layak \\
\hline $\mathrm{J}$ & $\begin{array}{l}\text { Situ Leungsir/ } \\
\text { Rawa Jelot }\end{array}$ & & & $\mathrm{v}$ & & & $\mathrm{v}$ & $\begin{array}{l}\text { Tidak } \\
\text { Layak }\end{array}$ \\
\hline $\mathrm{K}$ & $\begin{array}{l}\text { Situ Liang } \\
\text { Maung }\end{array}$ & & $\mathrm{v}$ & & & & $\mathrm{v}$ & $\begin{array}{l}\text { Tidak } \\
\text { Layak }\end{array}$ \\
\hline $\mathrm{L}$ & $\begin{array}{l}\text { Situ } \\
\text { Pagadungan }\end{array}$ & & & $\mathrm{v}$ & & & $\mathrm{v}$ & $\begin{array}{l}\text { Tidak } \\
\text { Layak }\end{array}$ \\
\hline M & Situ Taman & & $\mathrm{v}$ & & & & $\mathrm{v}$ & $\begin{array}{l}\text { Tidak } \\
\text { Layak }\end{array}$ \\
\hline $\mathrm{N}$ & $\begin{array}{l}\text { Situ Tegal } \\
\text { Abidin }\end{array}$ & & $\mathrm{v}$ & & & $\mathrm{v}$ & & Layak \\
\hline
\end{tabular}

Sumber : Hasil Analisis, 2018

\section{Kesimpulan dan Saran}

\section{Kesimpulan}

Berdasarkan penilaian analisis pada indikator kualitas fisik dan potensi pariwisata, diperoleh hasil bahwa terdapat 5 (lima) situ yang berpotensi dikembangkan menjadi objek wisata yaitu Situ Cibeureum, Situ Ceper, Situ Binong, Situ Cipalahar, dan Situ Tegal Abidin. Meskipun secara kondisi fisik situ-situ tersebut dalam kondisi terganggu, kecuali Situ Ceper, namun masih ada kegiatan pemeliharaan rutin yang dilakukan oleh BBWSCC.

Berdasarkan Tabel 5 tentang penilaian kondisi fisik situ, maka kondisi terganggu pada lima situ tersebut dikarenakan oleh penyusutan luasan situ. Sedangkan untuk parameter kondisi fisik lainnya berada pada kondisi yang layak untuk dikembangkan menjadi obyek destinasi wisata. Adapun hasil penilaian potensi pariwisata untuk Situ Ceper, Situ Binong, Situ Cipalahar, dan Situ Tegal Abidin termasuk yang memiliki cukup potensi untuk pengembangan kegiatan 
pariwisata. Sedangkan Situ Cibeureum dinilai sangat berpotensi untuk pengembangan kegiatan pariwisata, selain itu Situ Cibeureum sudah masuk dalam site plan kawasan perumahan Grand Wisata dan telah direncanakan akan dikembangkan oleh pihak Grand Wisata menjadi Celebration Lake dengan berbagai fasilitas hiburan.

\section{Saran}

Situ adalah sumber daya alam yang sangat penting karena menawarkan persediaan air tawar untuk mendukung berbagai kegiatan manusia, termasuk pertanian, perdagangan, transportasi, rekreasi, pariwisata, dan produksi pangan dan energi, juga menyediakan habitat penting bagi beragam organisme (Wuhan, 2009).

Beberapa masalah yang diperkirakan muncul sebagai pengaruh dari kegiatan pariwisata harus segera diatasi dengan mempertimbangkan implementasi dari program pemeliharaan lingkungan ekosistem situ. Penting untuk diterapkan peraturan yang dapat mengendalikan pengaruh wisata terhadap lingkungan situ, khususnya pada zonasi wisata guna melindungi situ. Sehingga tujuan pembangunan situ diprioritaskan pada pemeliharaan lingkungan situ serta meningkatkan standar ekonomi dan sosial masyarakat lokal. Tahapan roadmap pengembangan situ-situ di Kabupaten Bekasi sebagai destinasi wisata berkelanjutan, secara makro, antara lain: 1) Siapkan situ sebagai obyek destinasi wisata, melalui : rehabilitasi situ, upaya konservasi, dan sertifikasi lahan; 2) Menggalang kerjasama antara pemerintah, komunitas masyarakat, industri pariwisata dan mitra terkait lainnya untuk bersamasama berpartisipasi dalam perlindungan lingkungan ekosistem situ dan pariwisata berkelanjutan; 3) Rencana pengembangan jangka pendek mencakup : menciptakan keunikan daya tarik, iklim usaha yang kondusif, dan menyiapkan fasilitas penunjang wisata; 4) Membuat strategi manajemen jangka panjang untuk melindungi lingkungan situ dengan melibatkan peran masyarakat lokal; 5) Melibatkan masyarakat lokal dalam pembangunan situ sebagai obyek destinasi wisata, dan juga menjadi prioritas dalam pelibatan sebagai pekerja pramuwisata.

\section{Daftar Pustaka}

UNWTO (2014). Tourism Highlights. (https://www.eunwto.org/doi/pdf/10.18111/ 9789284416226) diunduh pada 1 Februari 2019.

Dokulil, MT (2014). Environmental Impacts of Tourism on Lakes. Eutrophication : Causes, Consequences and Control, Springer Science and Business Media Dordrecht, vol.2, pp.81-88.

Arofa, A. Rahman (2010). Potensi Pengembangan Situ di Kota Bogor Sebagai Objek Wisata, Tesis, Program Pascasarjana Magister Teknik Pembangunan Wilayah dan Kota, Universitas Diponegoro.

Muhtadi, A (2017). State of The Art "Pengelolaan Danau di Indonesia". (https://www.researchgate.net/publi cation/321803306) diunduh pada 1 Februari 2019.

Kutarga, ZW (2008). Kebijakan Pengelolaan Danau dan Waduk Ditinjau dari Aspek Tata Ruang. Wahana Hijau Jurnal Perencanaan dan Pengembangan Wilayah, vol.3, no.3, April 2008.

Tikkanen, I (2003). Classification of lake tourism activates in Finland: A 
resource approach. International

Lake Tourism Conference,

Savonlinna, Finland, University of Kuopio.

Puspita, L, dkk (2005). Lahan Basah Buatan di Indonesia. Wetlands International Indonesia Programe, Ditjen PHKA. Bogor, Juni 2005.

13 th Wuhan Declaration (2009). World Lake Conference : Rehabilitate the Lake Ecosystem : Global Challenges and the Chinese Innovations. http://www.pref.ibaraki.jp/ soshiki/seikatsukankyo/kasumigaura esc/04_kenkyu/kaigi/docments/kosy ou/utan/2009wlc-Wuhan-

Declaration.pdf) diunduh pada 1 Februari 2019. 